\title{
ANALISIS PENENTUAN PRIORITAS PENANGANAN JALAN DI KOTA DENPASAR BERDASARKAN METODE ANALYTIC HIERARCHY PROCESS (AHP) DENGAN KOMBINASI METODE FUZZY ANALYTIC HIERARCHY PROCESS (FAHP) DAN TOPSIS
}

\author{
Dwi Ayu Wira Savitri ${ }^{1}$, D. M. Priyantha Wedagama ${ }^{2}$, dan I G. Putu Suparsa ${ }^{2}$
}

\begin{abstract}
Abstrak: Penentuan prioritas penanganan jalan merupakan salah satu tugas penting yang dihadapi oleh para pengambil keputusan dan dianggap sebagai masalah multikriteria rumit. Diperlukan suatu sistem untuk menyaring dan menyusun urutan proyek, dengan berdasarkan pada beberapa kriteria.

Metode SK. No. 77 Dirjen Bina Marga Tahun 1990 mencerminkan metode eksisting yang digunakan di pemerintahan saat ini.Metode ini memiliki keterbatasan kriteria dalam menentukan urutan prioritas penanganan jalan.Sementara metode AHP, kombinasi metode FAHP dan TOPSIS merupakan metode alternatif teknik penentuan prioritas penanganan jalan yang menggabungkan berbagai kriteria yang juga dapat dipertimbangkan oleh para pengambil keputusan.

Bobot kriteria dengan AHP untuk faktor kondisi jalan, faktor volume lalu lintas, faktor ekonomi dan faktor kebijakan masing - masing sebesar 41,8\%, 25,4\%, 21,6\% dan 11,2\%. Sementara itu, dengan kombinasi metode FAHP dan TOPSIS bobot kriteria faktor kondisi jalan, faktor volume lalu lintas, faktor ekonomi dan faktor kebijakan masing - masing sebesar 33,8\%, 26,6\%, 24,7\% dan 14,9\%. Metode AHP dan FAHP memberikan hasil yang sama dalam urutan bobot kriteria, akan tetapi terdapat perubahan urutan pembobotan dalam tingkatan sub kriteria.Secara umum metodeAHPmemberikan hasilurutan prioritas penanganan jalan yang berbeda dengan metode SK. No. 77 Dirjen Bina Marga Tahun 1990.Di sisi lain, kombinasi metode FAHPdanTOPSISmemberikan hasil yang lebih mendekatimetodeSK. No. 77 Dirjen Bina Marga Tahun 1990.

Dalam menentukan skala prioritas penanganan jalan di Kota Denpasar, Pemerintah Kota sebaiknya mempertimbangkan penggunaan metode FAHP dan TOPSIS.Pertimbangan dari penggunaan metode FAHP dan TOPSIS dapat mengkombinasikan berbagai aspek dan kriteria yang dilakukan dengan pembobotan berdasarkan tingkat kepentingan, sehingga hasil urutan prioritas penanganan jalan yang dihasilkan lebih representatif.
\end{abstract}

Kata Kunci :Prioritas Penanganan Jalan, AHP, Fuzzy AHP, TOPSIS

\section{THE ANALYSIS OF ROAD HANDLING PRIORITY IN DENPASAR USING AN ANALYTIC HIERARCHY PROCESS (AHP) AND A COMBINATION BETWEEN FUZZY ANALYTIC HIERARCHY PROCESS (FAHP) AND TOPSIS METHODS}

\begin{abstract}
Abstrac :Road handling priority determination is an important tasks faced by decision makers and is regarded as a complex multi-criteria problem. It requires a system to categorise and ranks the project order using several criteria.

Officially, SK. No. 77 of the Directorate General of Highway issued in 1990 is a method used in the local government. This method however, has been considered to have limitations to determine road handling priority. Using previous studies, the Analytic Hierarchy Process (AHP) and the combination of FAHP and TOPSIS methods are considered relevant to determine road handling priority. These methods incorporates a variety of criteria which can also be considered by the decision makers.

Using the AHP, the criteria of road conditions, traffic volume, economic and policy factors are $41.8 \%, 25.4 \%, 21.6$ and $11.2 \%$ respectively. Meanwhile, a combination methods of FAHP and TOPSIS give the criteria of road conditions, traffic volume, economic and policy factors of $33.8 \%, 26.6 \%, 24.7 \%$ and $14.9 \%$ respectively. Both AHP and FAHP produce the same result in terms of criteria rank. This is not the case however, in the sub criteria rank. This study found that AHP gives road handling priority differently to the SK. No 77 of Directorate General of Highway (1990). In contrast, a combination methods of FAHP and TOPSIS produces road handling priority in the same way to the SK. No 77 of Directorate General of Highway (1990).

Denpasar city government is suggested to consider the use of FAHP and TOPSIS method in determining its road handling priority. This method is considered to have a capability to combine many criteria using a priority weighted score. The road handling priority results therefore, are more realistic.
\end{abstract}

Keywords : The priority of road handling, AHP, Fuzzy AHP, TOPSIS

\footnotetext{
${ }^{1}$ Mahasiswa Program Magister Teknik Sipil, Program Pascasarjana Universitas Udayana, Denpasar

${ }^{2}$ Staf Pengajar Program Magister Teknik Sipil, Program Pascasarjana Universitas Udayana, Denpasar
} 


\section{PENDAHULUAN \\ Latar Belakang}

Pedoman perencanaan jalan yang selama ini digunakan di Pemerintahan dalam menentukan skala prioritas penanganan jalan berdasarkan SK. No. 77 Dirjen Bina Marga Tahun 1990.Metode ini memiliki keterbatasan kriteria dalam menentukan urutan prioritas penanganan jalan, hanya berdasarkan data teknis dari Dinas Bina Marga.Sedangkan permasalahan yang dihadapi di lapangan sangat kompleks dan dipengaruhi oleh berbagai aspek kriteria.

Karena adanya keterbatasan kriteria dari SK. No. 77 Dirjen Bina Marga, maka pada beberapa studi sebelumnya (Karya, 2004; Suyasa, 2008; Putri, 2011) digunakan alternatif metode Analytic Hierarchy Process (AHP).Akan tetapi, seringkali didalam pengambilan keputusan, para pakar/ pengambil keputusan tidak memiliki informasi yang lengkap dan akurat tentang kondisi jalan.Metode AHP ini dikritisi kurang mampu mengatasi faktor tidak presisinya data (data masih bersifat kabur).Hal ini menyebabkan keragu - raguan pengambil keputusan ketika harus memberikan nilai yang pasti dalam matrik perbandingan berpasangan dari AHP. Untuk itu, Fuzzy AHP yang merupakan penggabungan antara metode AHP dengan pendekatan Fuzzy dapat digunakan untuk mengatasi kekaburan data/ ketidakpresisian data (Balli and Korokuglu, 2009; Dagdeviren, et.al,2009; Vahidnia, et.al 2008) dalam Wedagama (2010).

Pada penelitian ini, metode SK. No. 77 Dirjen Bina Marga Tahun 1990, metode AHP, kombinasi metode FAHP dan TOPSIS digunakan dan dibandingkan untuk menganalisis penentuan prioritas penanganan jalan di Kota Denpasar. Metode SK. No. 77 Dirjen Bina Marga Tahun 1990 mencerminkan metode eksisting yang digunakan di pemerintahan saat ini.Sementara metode AHP, kombinasi metode FAHP dan TOPSIS merupakan alternatif teknik penentuan prioritas penanganan jalan yang juga dapat dipertimbangkan oleh para pengambil keputusan.

\section{Rumusan Masalah}

1. Bagaimanakah perbandingan bobot kriteria dan sub kriteria dalam menentukan urutan prioritas penanganan jalan di Kota Denpasar berdasarkan metode Analytic Hierarchy Process (AHP), kombinasi metode FuzzyAnalytic Hierarchy Process (FAHP) dan TOPSIS?

2. Bagaimanakah urutan alternatif prioritas penanganan jalan di Kota Denpasar menggunakan metode SK. No. 77 Dirjen Bina Marga Tahun 1990, metode Analytic Hierarchy Process (AHP), kombinasi metode FuzzyAnalytic Hierarchy Process (FAHP) dan TOPSIS?

\section{Tujuan Penelitian}

1. Menganalisis perbandingan bobot kriteria dan sub kriteria dalam menentukan urutan prioritas penanganan jalan di Kota Denpasar dengan metode Analytic Hierarchy Process (AHP), kombinasi metode FuzzyAnalytic Hierarchy Process (FAHP) dan TOPSIS.

2. Menganalisis urutan alternatif prioritas penanganan jalan di Kota Denpasar menggunakan metode SK. No. 77 Dirjen Bina Marga Tahun 1990, metode Analytic Hierarchy Process (AHP), kombinasi metode FuzzyAnalytic Hierarchy Process (FAHP) dan TOPSIS.

\section{TINJAUAN PUSTAKA}

Penentuan Skala Prioritas dengan Metode AHP

Secara grafis, persoalan keputusan AHP dapat dikonstruksikan sebagai diagram bertingkat, yang dimulai dengan goal/ sasaran, lalu kriteria level pertama, sub kriteria dan akhirnya alternatif. AHP memungkinkan pengguna untuk memberikan nilai bobot relatif dari suatu kriteria majemuk (atau alternatif majemuk terhadap suatu kriteria) secara intuitif, yaitu dengan melakukan perbandingan berpasangan (Pairwise Comparisons). Saaty (1986) menentukan cara yang konsisten untuk mengubah perbandingan berpasangam atau pairwise menjadi suatu himpunan bilangan yang mempresentasikan prioritas relatif dari setiap kriteria dan alternatif. Perbandingan berpasangan diulang untuk semua elemen dalam tiap tingkat. Elemen dengan bobot paling tinggi adalah pilihan keputusan yang layak dipertimbangkan untuk diambil. Untuk model AHP matrik perbandingan dapat diterima jika nilai ratio konsisten tidak lebih dari $10 \%$ atau sama dengan 0,1 . Sedangkan kelemahanmetodeAHP adalah ketergantungan model AHP pada input utamanya. Input utama ini berupa persepsi seorang ahli sehingga dalam hal ini melibatkan subyektifitas para 
ahli selain itu juga model menjadi tidak berarti jika ahli tersebut memberikan penilaian yang keliru.

Pemberian nilai preferensi berpasangan dengan nilai dalam skala 1 sampai dengan 9 dari skala Saaty (1986), antar unsur dalam satu tingkat dari struktur hirarki oleh pihak yang berkompeten dibidangnya.

Tabel 1. Skala Matrik Perbandingan Berpasangan

\begin{tabular}{|c|c|c|}
\hline $\begin{array}{c}\text { Intensitas } \\
\text { Kepentingan }\end{array}$ & Definisi & Penjelasan \\
\hline 1 & $\begin{array}{l}\text { Elemen yang sama } \\
\text { pentingnya dibanding } \\
\text { dengan elemen yang } \\
\text { lain (Equal importance) }\end{array}$ & $\begin{array}{l}\text { Kedua elemen } \\
\text { menyumbang sama } \\
\text { besar pada sifat } \\
\text { tersebut }\end{array}$ \\
\hline 3 & $\begin{array}{l}\text { Elemen yang satu } \\
\text { sedikit lebih penting } \\
\text { dari pada elemen yang } \\
\text { lain (Moderate more } \\
\text { importance) }\end{array}$ & $\begin{array}{l}\text { Pengalaman } \\
\text { menyatakan sedikit } \\
\text { berpihak pada satu } \\
\text { elemen }\end{array}$ \\
\hline 5 & $\begin{array}{l}\text { Elemen yang satu jelas } \\
\text { lebih penting dari pada } \\
\text { elemen lain (Essential, } \\
\text { strong more important) }\end{array}$ & $\begin{array}{l}\text { Pengalaman } \\
\text { meunjukkan secara } \\
\text { kuat memihak pada } \\
\text { satu elemen }\end{array}$ \\
\hline 7 & $\begin{array}{l}\text { Elemen yang satu sangat } \\
\text { jelas lebih penting dari } \\
\text { pada elemen yang lain } \\
\text { (Drmonstrated } \\
\text { importance) }\end{array}$ & $\begin{array}{l}\text { Pengalaman } \\
\text { menunjukkan } \\
\text { secara kuat disukai } \\
\text { dan dominannya } \\
\text { terlihat praktek } \\
\end{array}$ \\
\hline 9 & $\begin{array}{l}\text { Elemen yang satu } \\
\text { mutlak lebih penting } \\
\text { dari elemen yang lain } \\
\text { (Absolutely more } \\
\text { importance) }\end{array}$ & $\begin{array}{l}\text { Pengalaman } \\
\text { menunjukkan satu } \\
\text { elemen sangat jelas } \\
\text { dan penting }\end{array}$ \\
\hline $2,4,6,8$ & $\begin{array}{l}\text { Apabila ragu - ragu } \\
\text { antara dua nilai ruang } \\
\text { berdekatan (grey area) }\end{array}$ & $\begin{array}{l}\text { Nilai ini diberikan } \\
\text { bila diperlukan } \\
\text { kompromi }\end{array}$ \\
\hline
\end{tabular}

Sumber : Saaty, 1986

Perhitungan dalam penentuan prioritas jalan dengan metode ini dilakukan sesuai dengan kelompok penanganannya yaitu : pemeliharaan rutin jalan, pemeliharaan berkala jalan, dan peningkatan jalan. Selanjutnya dalam perhitungan menggunakan model matematis yang dihitung dengan sistem persamaan matematis menurut Brodjonegoro (1991) sesuai dengan kelompok penanganannya adalah :

$$
\begin{aligned}
\mathrm{Y}= & \mathrm{A}(\mathrm{a} 1 \mathrm{x} \text { bobot } \mathrm{a} 1+\ldots \ldots+\mathrm{a} 6 \mathrm{x} \text { bobot } \mathrm{a} 6) \\
& +\ldots \ldots+\mathrm{D}(\mathrm{d} 1 \mathrm{x} \text { bobotd } 1+\ldots .+\mathrm{d} 3 \mathrm{x} \\
& \text { bobot } \mathrm{d} 3)
\end{aligned}
$$

\section{Himpunan Fuzzy}

Teori himpunan Fuzzyini pertama kali diperkenalkanolehZadehpada tahun 1965(Balli andKorukoğlu, 2009;Dagdeviren, et.al, 2009; Vahidnia, et.al, 2008) dalam Wedagama (2010) Teori ini dikembangkankarenarasionalitasketidakpastian akibatketidaktepatanatau

ketidakjelasan.Himpunandanlogika fuzzydapat mewakilidata yang bersifat "kabur"dan dapat digunakan untuk menyusun modelmatematikauntuk pengambilan keputusankarena tidak adanyainformasi yang lengkap danakurat.Segitiga dan trapesium bilangan Fuzzy yang umum digunakan dalam aplikasi nyata dan lebih nyata bekerja dengan bilangansegitigaFuzzy TFN(Triangular Fuzzy Number) karena memiliki perhitungan sederhana. Selain itu, untuk lebih praktis dalam menggambarkan proses kerja di lingkungan Fuzzy. Sejumlah segitiga Fuzzy, $\mathrm{M}$ ditunjukkan pada Gambar 1. (Balli and Korukoğlu, 2009) dalam Wedagama (2010)

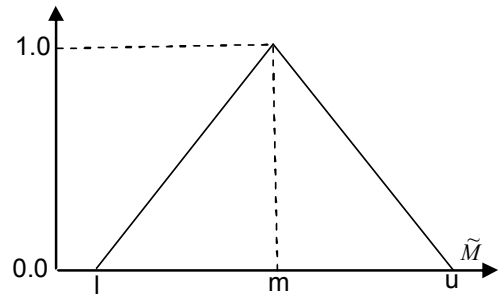

Gambar 1. Segitiga Fuzzy $\tilde{M}$

TFNditandaidengan tigabilangan real, dinyatakan sebagai $(1, \mathrm{~m}, \mathrm{u})$. Parameterl, $\mathrm{m}$ danumasing - masing tentukansekecil mungkin,yang paling menjanjikandanterbesarkemungkinan nilaiyang menggambarkanperistiwakabur. Fungsi keanggotaandigambarkansebagai berikut:

$\mu(\mathrm{x} / \tilde{M})= \begin{cases}0, & \mathrm{x}<1, \\ (\mathrm{x}-1) /(\mathrm{m}-\mathrm{l}), & 1 \leq \mathrm{x} \leq \mathrm{m} \\ (\mathrm{u}-\mathrm{x}) /(\mathrm{u}-\mathrm{m}), & \mathrm{m} \leq \mathrm{x} \leq \mathrm{u} \\ 0, & \mathrm{x}>\mathrm{u}\end{cases}$

Ada banyakoperasi padabilangan segitigaFuzzy. Namun, dalamtulisan inihanya menjelaskantiga operasi dasar. Ada duasegitigabilangan Fuzzypositifterdiri $\left(\mathrm{l}_{1}, \mathrm{~m}_{1}\right.$, $\left.\mathrm{u}_{1}\right) \operatorname{dan}\left(\mathrm{l}_{2}, \mathrm{~m}_{2}, \mathrm{u}_{2}\right)$ sehingga:

$\left(\mathrm{l}_{1}, \mathrm{~m}_{1}, \mathrm{u}_{1}\right)+\left(\mathrm{l}_{2}, \mathrm{~m}_{2}, \mathrm{u}_{2}\right)=\left(\mathrm{l}_{1}+\mathrm{l}_{2}, \mathrm{~m}_{1}+\mathrm{m}_{2}, \mathrm{u}_{1}+\mathrm{u}_{2}\right)$

$\left(l_{1}, \mathrm{~m}_{1}, \mathrm{u}_{1}\right) \cdot\left(\mathrm{l}_{2}, \mathrm{~m}_{2}, \mathrm{u}_{2}\right)=\left(\mathrm{l}_{1} \cdot \mathrm{l}_{2}, \mathrm{~m}_{1} \cdot \mathrm{m}_{2}, \mathrm{u}_{1} \cdot \mathrm{u}_{2}\right)$

$$
\left(\mathrm{l}_{1}, \mathrm{~m}_{1}, \mathrm{u}_{1}\right)^{-1} \approx\left(\frac{1}{u_{1}}, \frac{1}{m_{1}}, \frac{1}{l_{1}}\right)
$$




\section{Fuzzy AHP}

Untuk mengatasi kelemahan AHP maka dikembangkan suatu metode yang disebut Fuzzy AHP.Fuzzy AHP dapat diintegrasikan dengan perbandingan berpasangan sebagai perpanjangan dari AHP (Chang, 1996 di Vahidnia, et.al, 2008; Kwong dan Bai, 2002) dalam Wedagama (2010).Pada metode Fuzzy AHP digunakan Triangular Fuzzy Number (TFN).TFN digunakan untuk menggambarkan variabel - variabel linguistik secara pasti. TFN disimbolkan dengan $\tilde{M}=l, m, u$, dimana $l \leq m \leq u$ dan $l$ adalah nilai terendah, $m$ adalah nilai tengah, dan $u$ adalah teratas. TFN ini digunakan untuk membangun perbandingan matrik (kriteria dan sub kriteria) dari FAHP didasarkan pada teknik perbandingan berpasangan.

Tabel 2. Konversi Nilai Tunggal Matriks Perbandingan Berpasangan ke Nilai Fuzzy

\begin{tabular}{|c|c|c|c|}
\hline $\begin{array}{c}\text { Nilai } \\
\text { PCM } \\
\text { Tunggal }\end{array}$ & $\begin{array}{c}\text { Nilai PCM } \\
\text { Fuzzy }\end{array}$ & $\begin{array}{c}\text { Nilai } \\
\text { PCM } \\
\text { Tunggal }\end{array}$ & $\begin{array}{c}\text { Nilai PCM } \\
\text { Fuzzy }\end{array}$ \\
\hline 1 & $\begin{array}{c}(1,1,1) \text { jika } \\
\text { diagonal, } \\
\text { lainnya } \\
(1,1,3)\end{array}$ & $1 / 1$ & $\begin{array}{c}(1 / 1,1 / 1,1 / 1) \\
\text { jika diagonal, } \\
\text { lainnya } \\
(1 / 3,1 / 1,1 / 1)\end{array}$ \\
\hline 2 & $(1,2,4)$ & $1 / 2$ & $(1 / 4,1 / 2,1 / 1)$ \\
\hline 3 & $(1,3,5)$ & $1 / 3$ & $(1 / 5,1 / 3,1 / 1)$ \\
\hline 5 & $(3,5,7)$ & $1 / 5$ & $(1 / 7,1 / 5,1 / 3)$ \\
\hline 7 & $(5,7,9)$ & $1 / 7$ & $(1 / 9,1 / 7,1 / 5)$ \\
\hline 9 & $(7,9,11)$ & $1 / 9$ & $(1 / 11,1 / 9,1 / 7)$ \\
\hline
\end{tabular}

Sumber : Prakash, 2003

Asumsikan $X=\{x 1, x 2, x 3$, $\mathrm{xn}\}$ adalah himpunanobyek dan $\mathrm{G}=\{\mathrm{g} 1, \mathrm{~g} 2, \mathrm{~g} 3$, ....,gn $\}$ adalah seperangkattujuan. Menurut analisisFuzzy(Chang, 1992diBallidanKorukoglu, 2009) dalam Wedagama (2010), setiap objekdiambildan dilakukan analisisuntuk setiap tujuan, dilakukan untuk masing - masing gi.Oleh karena itu, nilai - nilai manalisissejauhuntuk setiap objekyang dapat diperoleh, dengantanda - tanda berikut:

$M^{1} g_{i}, M^{2} g_{i}, \ldots \ldots \ldots \ldots \ldots . M^{m} g_{i}$, untuk $i=1,2$, n, di manaM $\mathrm{g}_{\mathrm{i}} \mathrm{j}=1,2$,

m) untuk semuaTFNs.Metode analisisdapat digambarkanmenjadi beberapa langkahsebagai berikut(Chang, 1992 diBallidanKorukoglu, 2009) dalam Wedagama (2010) :

Langkah1:

Nilai

batasFuzzysintetiksehubungan

denganobjeki ${ }^{\text {th }}$ didefinisikan sebagai:

$$
\mathrm{S}_{\mathrm{i}}=\sum_{j=1}^{m} M_{g_{i}}^{j} \otimes\left[\sum_{i=1}^{n} \sum_{j=1}^{m} M_{g_{i}}^{j}\right]^{-1}
$$

Untuk mendapatkan $\sum_{j=1}^{m} M_{g_{i}}^{j}, \quad$ operasi penjumlahannilai m Fuzzydengan analisisyang dilakukanuntuk matrikstertentusehingga

$$
\begin{aligned}
& \sum_{j=1}^{m} M_{g_{i}}^{j}=\left(\sum_{j=1}^{m} l_{j}, \sum_{j=1}^{m} m_{j}, \sum_{j=1}^{m} u_{j}\right) \\
& \text { dan untuk mendapatkan }\left[\sum_{i=1}^{n} \sum_{j=1}^{m} M_{g_{i}}^{j}\right]^{-1}
\end{aligned}
$$

,operasi penjumlahanFuzzy $\mathrm{M}_{\mathrm{i}}^{\mathrm{j}} \mathrm{g}_{\mathrm{i}}(\mathrm{j}=1,2, \ldots, \mathrm{m})$ nilaidilakukansedemikian rupa sehingga

$$
\sum_{i=1}^{n} \sum_{j=1}^{m} M_{g_{i}}^{j}=\left(\sum_{i=1}^{n} l_{i}, \sum_{i=1}^{n} m_{i}, \sum_{i=1}^{n} u_{i}\right)
$$

Kebalikan darivektordiatasdihitungsedemikian rupa sehingga

$$
\left[\sum_{i=1}^{n} \sum_{j=1}^{m} M_{g_{i}}^{j}\right]^{-1}=\left(\frac{1}{\sum_{i=1}^{n} u_{i}}, \frac{1}{\sum_{i=1}^{n} m_{i}}, \frac{1}{\sum_{i=1}^{n} l_{i}}\right)
$$

Langkah2: $\operatorname{Sejak} \widetilde{M}_{1}=\left(1_{1}, \mathrm{~m}_{1}, \mathrm{u}_{1}\right)$ dan $\widetilde{M}_{2}=$ $\left(1_{2}, \mathrm{~m}_{2}, \mathrm{u}_{2}\right)$ adalah duabilangan segitiga Fuzzy, tingkatkemungkinan $\mathrm{M}_{2}=\left(\mathrm{l}_{2}, \mathrm{~m}_{2}, \mathrm{u}_{2}\right) \geq \mathrm{M}_{1}=$ $\left(1_{1}, \mathrm{~m}_{1}, \mathrm{u}_{1}\right)$ didefinisikan sebagai:

$$
\begin{aligned}
& \mathrm{V}\left(\tilde{M}_{2} \geq \tilde{M}_{1}\right)=\operatorname{hgt}\left(\tilde{M}_{2} \cap \widetilde{M}_{1}\right)=\mu_{M_{2}}(d) \\
& = \begin{cases}1, & \text { jika } \mathrm{m}_{2} \geq \mathrm{m}_{1} \\
0, & \text { jika } \mathrm{l}_{1} \geq \mathrm{u}_{2} \\
\frac{l_{1}-u_{2}}{\left(m_{2}-u_{2}\right)-\left(m_{1}-l_{1}\right)}, & \text { Sebaliknya, }\end{cases}
\end{aligned}
$$

\section{Langkah3:}

Tingkatkemungkinansejumlahbilangan Fuzzy lebih besar darikFuzzy $\mathrm{M}_{\mathrm{i}} \quad(\mathrm{i}=1,2, \ldots \ldots, \mathrm{k})$ dapatdidefinisikan sebagai:

$\mathrm{V}\left(\mathrm{M} \geq \mathrm{M}_{1}, \mathrm{M}_{2}, \ldots . . \mathrm{M}_{\mathrm{k}}\right)=\mathrm{V}\left[\left(\mathrm{M} \geq \mathrm{M}_{1}\right)\right.$ dan $\left(\mathrm{M} \geq \mathrm{M}_{2}\right)$ dan......(M $\left.\left.\geq \mathrm{M}_{\mathrm{k}}\right)\right]=\min \mathrm{V}[(\mathrm{M} \geq$ $\left.\mathrm{M}_{\mathrm{i}}\right), \mathrm{i}=1,2 \ldots, \mathrm{k}$

Pada asumsi bahwa $d\left(\mathrm{~A}_{\mathrm{i}}\right)=\min \mathrm{V}\left(\mathrm{S}_{\mathrm{i}} \geq \mathrm{S}_{\mathrm{k}}\right)$ dari $\mathrm{k}=1,2, \ldots . . \mathrm{n} ; \mathrm{k} \neq \mathrm{i}$, vektor bobot diberikan olehW' $=\left(\mathrm{d}^{\prime}\left(\mathrm{A}_{1}\right)\right.$, $\left.d^{\prime}\left(A_{2}\right), \ldots \ldots . . d^{\prime}\left(A_{n}\right)\right)^{T}$

dimana $A_{i}=(i=1,2, \ldots \ldots . n)$ adalah elemen $n$.

Langkah4: Vektor berat dinormalisasi diperoleh sebagai berikut: $W=\left(d\left(A_{1}\right), d\left(A_{2}\right), \ldots \ldots . . d\left(A_{n}\right)\right)^{T}$ 
dimana W adalah bilangan non Fuzzy dan dihitung untuk setiap kriteria utama dan sub kriteria.Metode TOPSIS kemudian dilakukan untuk menentukan peringkat akhir dari alternatif.

\section{TOPSIS}

Metode TOPSIS (Technique for Order Preference by Similarity to Ideal Solution) mendefinisikan duajenissolusi ideal termasuksolusipositif dan solusi negatif.MetodeTOPSISuntuk penentuan urutan alternatif dihitungmenjadi beberapa langkahsebagai berikut(Hwang andYoon, 1981 diBallidanKorukoglu, 2009) dalam Wedagama (2010) :

\section{Langkah1.}

Keputusanmatrikdinormalisasimenggunakanpe rsamaan:

$\mathrm{r}_{\mathrm{ij}}=\frac{w_{i j}}{\sqrt{\sum_{j=1}^{J} w_{i j}^{2}}} \mathrm{j}=1,2,3, \ldots \ldots \ldots \ldots$,

$\mathrm{J} ; \mathrm{i}=1,2,3, \ldots \ldots \ldots \ldots \ldots \ldots \ldots \ldots \mathrm{n}$

Langkah 2. Tertimbang normalisasi matriks keputusan dibuat:

$\mathrm{v}_{\mathrm{ij}}=\mathrm{W}_{\mathrm{ij}} * \mathrm{r}_{\mathrm{ij}}, \mathrm{j}=1,2,3, \ldots \ldots \ldots \ldots$,

$\mathrm{J} ; \mathrm{i}=1,2,3, \ldots \ldots \ldots \ldots \ldots \ldots \mathrm{n}$

Langkah 3.Solusi idealpositif (PIS) dansolusi idealnegatif(NIS) ditentukan:

$\mathrm{A}^{*}=\left\{v_{1}^{*}, v_{2}^{*}, \ldots \ldots \ldots \ldots \ldots \ldots v_{n}^{*}\right\}$

Maximum values

$\mathrm{A}^{-}=\left\{v_{1}^{-}, v_{2}^{-}\right.$, $\left.v_{n}^{-}\right\}$

Minimum values

Langkah 4.Solusi idealpositif (PIS) dansolusi idealnegatif(NIS) ditentukan:

$$
\begin{aligned}
& d_{i}^{*}=\sqrt{\sum_{j=1}^{n}\left(v_{i j}-v_{j}^{*}\right)^{2}}, \mathrm{j}=1,2, \ldots \ldots \ldots \ldots \mathrm{J} \\
& d_{i}^{-}=\sqrt{\sum_{j=1}^{n}\left(v_{i j}-v_{j}^{-}\right)^{2}}, \mathrm{i}=1,2, \ldots \ldots \ldots \ldots \mathrm{J}
\end{aligned}
$$

Langkah 5.KoefisienKedekatansetiap alternatifdihitung:

$$
\mathrm{CC}_{\mathrm{i}}=\frac{d_{i}^{-}}{d_{i}^{*}+d_{i}^{-}}, \mathrm{i}=1,2, \ldots \ldots \ldots \ldots \ldots \ldots \mathrm{J}
$$

Langkah6. Dengan membandingkannilaiCCI, peringkatalternatifditentukan

\section{METODE PENELITIAN \\ Tahapan Penelitian}

Data primer dalam penelitian ini diperoleh melalui kuisioner atau wawancara kepada pihak - pihak (stakeholder) yang berkompeten dalam penanganan jalan di Kota Denpasar. Penyebaran kuisioner dengan wawancara langsung kepada responden yang mempunyai tugas, fungsi dan pengalaman di bidang penanganan dan perencanaan jalan sebanyak 25 responden.

Data Sekunder yang diperlukan dalam penelitian ini adalah data kondisi jalan, data lalu lintas harian rata - rata, dana anggaran/ biaya penanganan jalan per meter persegi dan data kebijakanpenanganan jalan di Kota Denpasar pada tahun anggaran 2012 - 2014 serta pedoman perencanaan jalan sesuai SK. No. 77 Dirjen Bina Marga Tahun 1990.

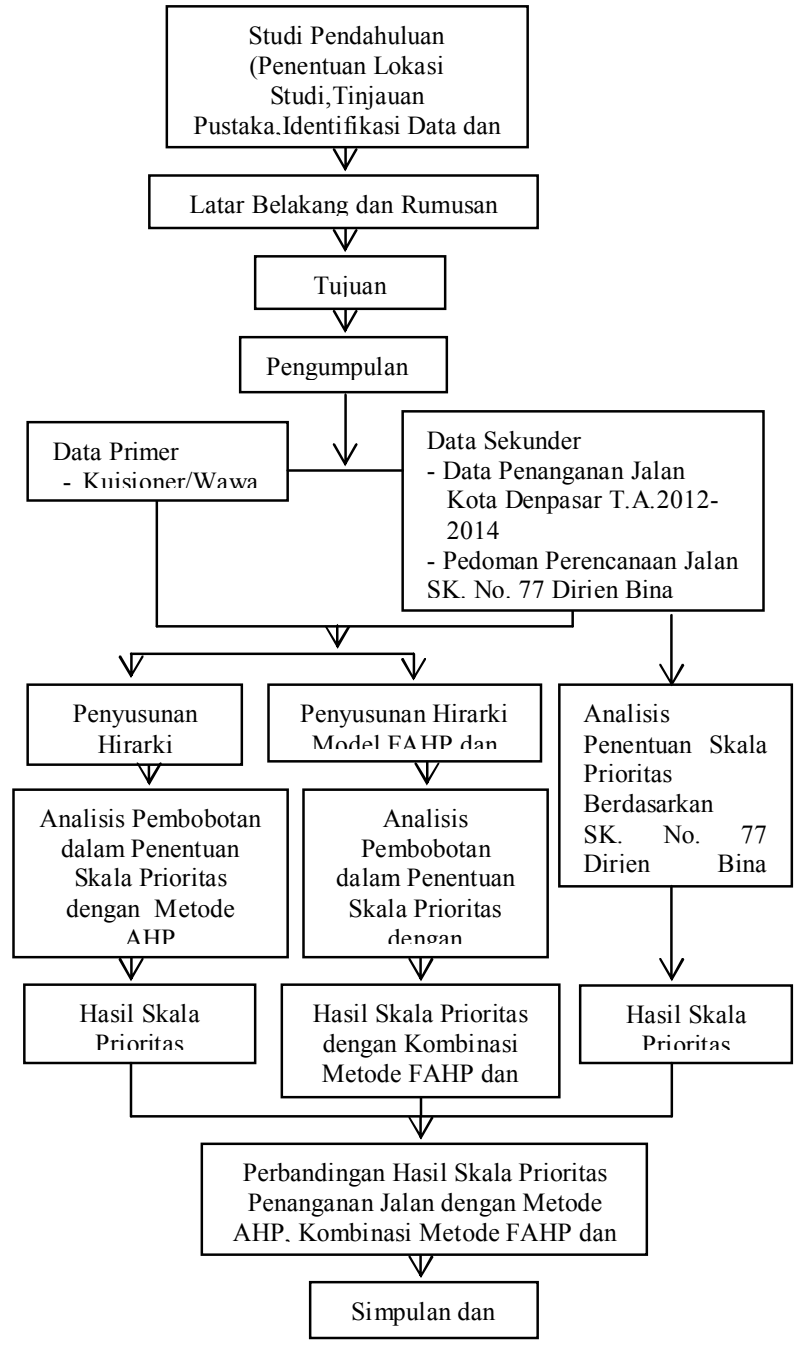

Gambar 2.Langkah - Langkah Penelitian 


\section{Lokasi Penelitian}

Lokasi penelitian merupakan ruas jalan di kota Denpasar yang pemeliharaannya berada di bawah Pemerintah Kota Denpasar, dengan dana penanganan yang berasal dari APBD Kota Denpasar.

\section{HASIL DAN PEMBAHASAN}

Prioritas Penanganan Jalan denganMetode AHP

Dari hasil identifikasi kriteria kepada responden yang terdiri dari 3 (tiga) level, yaitu levelpertama adalah tujuan yaitu Penentuan Skala Prioritas Penanganan Jalan di Kota Denpasar, level kedua terdiri dari 4 faktor yaitu : Faktor Kondisi Jalan, Faktor Volume Lalu Lintas, Faktor Ekonomi dan Faktor Kebijakan. Level ketiga merupakan pengembangan dari level kedua yang terdiri dari beberapa sub kriteria.Setelah ditentukan besaran bobot pada masing - masing elemen maka untuk menentukan skala prioritas penanganan jalan dengan Metode Analityc Hierarcy Process (AHP) dilanjutkan dengan penentuan urutan prioritas ruas jalan.
Perhitungan urutan prioritas penanganan ruas jalan dengan persamaan Brodjonegoro (1991) yang hasilnya diberi kode Y. Selanjutnya nilai $\mathrm{Y}$ pada semua ruas jalan diurut kembali berdasarkan nilai $\mathrm{Y}$ dari nilai terbesar sampai terkecil pada setiap kelompok penanganan jalan. Dalam studi ini, prioritaspenangananjalandengan analisis perbandingan metode SK. No 77 Dirjen Bina Marga Tahun 1990, metode AHP, kombinasi metode FAHP dan TOPSIS pada delapan ruas jalan kota pada kelompok kondisi rusak.

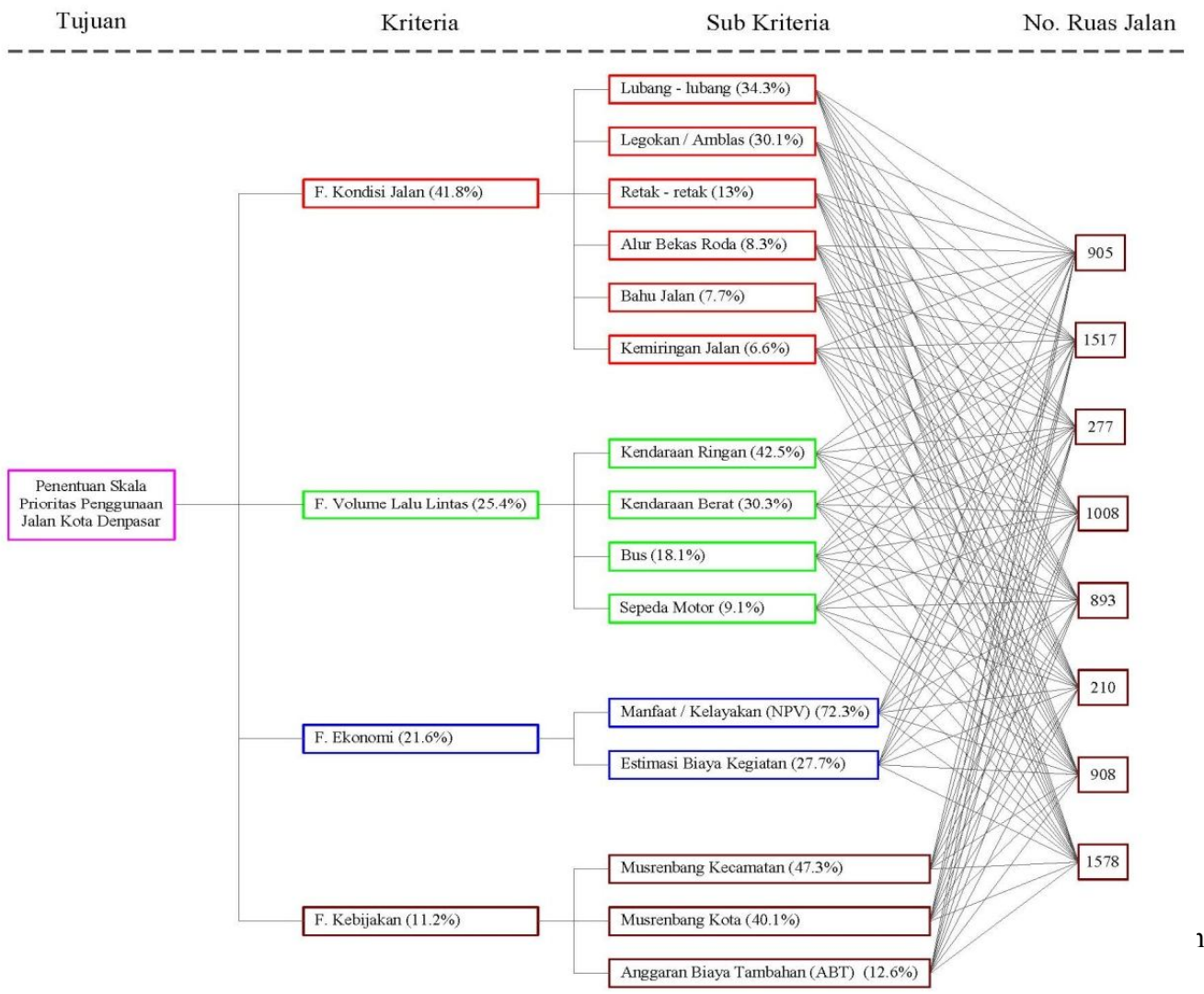

Gambar 3. Bobot Hirarki Penentuan Skala Prioritas Penanganan Jalan dengan Metode AHP untuk Kelompok Jalan dengan Kondisi Rusak 
menentukan matrik awal Faktor Kriteria, kemudian dengan menggunakan TFN $\mathrm{f}=(\mathrm{l}, \mathrm{m}, \mathrm{u})$ untuk menyusun perbandingan matrik dari FAHP yang didasarkan pada teknik perbandingan berpasangan.

\section{Menentukan Nilai Perbandingan Berpasangan}

Untuk menentukan bobot dalam skala prioritas penanganan jalan di Kota Denpasar dengan metode FAHP dimulai dengan menentukan Matrik Awal yang didapat dari perhitungan sebelumnya dengan Metode AHP. Adapun matrik awal dari Kriteria adalah sebagai berikut :

a. Matrik Awal Kriteria

\begin{tabular}{c|cccc} 
& $\mathrm{A}$ & $\mathrm{B}$ & $\mathrm{C}$ & $\mathrm{D}$ \\
\hline $\mathrm{A}$ & 1 & 2 & 2 & 3 \\
$\mathrm{~B}$ & 0 & 1 & 1 & 2 \\
$\mathrm{C}$ & 1 & 1 & 1 & 2 \\
$\mathrm{D}$ & 0 & 0 & 0 & 1
\end{tabular}

Keterangan :

$\mathrm{A}=$ Faktor Kondisi Jalan

$\mathrm{C}=$ Faktor Ekonomi

$\mathrm{B}=$ Faktor Volume Lalu Lintas

$\mathrm{D}=$ Faktor Kebijakan

Konversi Nilai Tunggal Matrik Perbandingan Berpasangan ke Nilai Fuzzy Dengan menggunakan Tabel 2. Konversi Nilai Tunggal Matrik Perbandingan Berpasangan ke Nilai Fuzzy, matrik awal kriteria yang bernilai tunggal dikonversi ke dalam nilai fuzzy.

a. Konversi nilai tunggal matrik berpasangan ke nilai Fuzzy pada Kriteria

\begin{tabular}{|c|c|c|c|c|c|c|c|c|c|c|c|c|}
\hline & \multicolumn{3}{|c|}{ A } & \multicolumn{3}{|c|}{ B } & \multicolumn{3}{|c|}{ C } & \multicolumn{3}{|c|}{ D } \\
\hline A & 1.000 & 1.000 & 1.000 & 1.000 & 2.000 & 4.000 & 1.000 & 2.000 & 4.000 & 1.000 & 3.000 & 5.000 \\
\hline B & 0.250 & 0.500 & 1.000 & 1.000 & 1.000 & 1.000 & 1.000 & 1.000 & 3.000 & 1.000 & 2.000 & 4.000 \\
\hline $\mathrm{C}$ & 0.250 & 0.500 & 1.000 & 0.333 & 1.000 & 1.000 & 1.000 & 1.000 & 1.000 & 1.000 & 2.000 & 4.000 \\
\hline D & 0.200 & 0.333 & 1.000 & 0.250 & 0.500 & 1.000 & 0.250 & 0.500 & 1.000 & 1.000 & 1.000 & 1.000 \\
\hline
\end{tabular}

Perhitungan Bobot Kriteria

Dari matrik yang telah dikonversi diatas, masing - masing nilai atas (1), nilai tengah (m) dan nilai bawah (u) dijumlahkan, sehingga didapat hasil sebagai berikut :

$$
\begin{aligned}
& \mathrm{li}=11,53 \\
& \mathrm{mi}=19,33 \\
& \mathrm{ui}=34,00
\end{aligned}
$$

Selanjutnya untuk perhitungan bobot kriteria sesuai dengan metode analisis yang dapat digambarkan menjadi beberapa langkah sebagai berikut :
Langkah 1 : Nilai batas fuzzy sintetik untuk kriteria sebagai berikut :

$\mathrm{ScA}=(4.00,8.00,14.00) \otimes(1 / 34,1 / 19.33$, $1 / 11.53)=(0.118,0.414,1.214)$,

$\mathrm{ScB}=(3.25,4.50,9.00) \otimes(1 / 34,1 / 19.33$, $1 / 11.53)=(0.096,0.233,0.780)$,

$\mathrm{ScC}=(2.58,4500,7.00) \otimes(1 / 34,1 / 19.33$, $1 / 11.53)=(0.076,0.233,0.607)$,

$\mathrm{ScD}=(1.70,2.33,4.00) \otimes(1 / 34,1 / 19.33$, $1 / 11.53)=(0.050,0.121,0.347)$,

Langkah 2 : Nilai fuzzy dibandingkan, dimana bilangan segitiga fuzzy dengan tingkat kemungkinan $\mathrm{M}_{2}=\left(\mathrm{l}_{2}, \mathrm{~m}_{2}, \mathrm{u}_{2}\right) \geq \mathrm{M}_{1}=\left(\mathrm{l}_{1}, \mathrm{~m}_{1}\right.$, $\mathrm{u}_{1}$ ) sebagai berikut :

$\mathrm{V}(\mathrm{ScA} \geq \mathrm{ScB})=1.00, \quad \mathrm{~V}(\mathrm{ScA} \geq \mathrm{ScC})=1.00$,

$\mathrm{V}(\mathrm{ScA} \geq \mathrm{ScD}) \quad=1.00$

$\mathrm{V}(\mathrm{ScB} \geq \mathrm{ScA})=0.785, \mathrm{~V}(\mathrm{ScB} \geq \mathrm{ScC})=1.00$

$\mathrm{V}(\mathrm{ScB} \geq \mathrm{ScD})=1.00$

$\mathrm{V}(\mathrm{ScC} \geq \mathrm{ScA})=0.730, \mathrm{~V}(\mathrm{ScC} \geq \mathrm{ScB})=1.00$,

$\mathrm{V}(\mathrm{ScC} \geq \mathrm{ScD})=1.00$

$\mathrm{V}(\mathrm{ScD} \geq \mathrm{ScA})=0.439, \mathrm{~V}(\mathrm{ScD} \geq \mathrm{ScB})=0.692$,

$\mathrm{V}(\mathrm{ScD} \geq \mathrm{ScC})=0.707$

Langkah 3 : Menentukan bobot prioritas sebagai berikut :

$\mathrm{d}^{\prime}(\mathrm{A})=\min (1.00,1.00,1.00) \quad=1.00$

$\mathrm{d}^{\prime}(\mathrm{B})=\min (0.785,1.00,1.00) \quad=0.785$

$\mathrm{d}^{\prime}(\mathrm{C})=\min (0.730,1.00,1.00) \quad=0.730$

$\mathrm{d}^{\prime}(\mathrm{A})=\min (0.439,0.692,0,707)=0.439$

Langkah 4 : Vektor berat W' dinormalisasikan menjadi $\mathrm{W}$, dimana $\mathrm{W}$ adalah bilangan non fuzzy dan dihitung untuk setiap kriteria utama. Berdasarkanhasil perhitungan diatas, berat vektorW'adalah(1.00, 0.785 , 0.730 ,

$0.439)$ danberatnormalisasivektorWadalahsama dengan $(0.338,0.266,0.247,0.149)$. Sehingga bobot masing - masing kriteria adalah :

Faktor Kondisi Jalan $\quad=0.338=33.8 \%$ Faktor Volume Lalu Lintas $=0.266=26.6 \%$

Faktor Ekonomi $\quad=0.247=24.7 \%$

Faktor Kebijakan $\quad=0.149=14.9 \%$

Vektorbobotuntuksubkriteriadihitungdengan cara yang samaseperti dengankriteria utama.

Penentuan Urutan Prioritas Penanganan Jalan dengan Metode TOPSIS

Penentuan urutan alternatif prioritas penanganan jalan dengan metode TOPSIS untuk kelompok jalan dengan Kondisi Rusak dengan 8 (delapan) ruas jalan dihitung sebagai berikut :

a. Normalisasi matrik dibangun dengan mengalikan setiap nilai dengan bobotnya masing - masing.

b. Jumlah nilai bobot dari masing - masing kriteria didapat dengan menormalisasi 
matrik keputusan. Untuk jumlah nilai bobot dari kriteria dapat dilihat pada Tabel 3 berikut ini.

Tabel 3. Nilai Bobot Kriteria

\begin{tabular}{|c|c|c|c|c|c|c|}
\hline No & No. Ruas & Nama Jalan & A & B & $\mathrm{C}$ & $\mathrm{D}$ \\
\hline 1 & 1008 & Jl. Tukad Barito & 0.032 & 0.030 & 0.010 & 0.013 \\
\hline 2 & 1517 & Jl. Antasura & 0.031 & 0.031 & 0.021 & 0.013 \\
\hline 3 & 905 & Jl. Waturenggong & 0.030 & 0.038 & 0.007 & 0.013 \\
\hline 4 & 908 & Jl. Tukad Banyupoh & 0.031 & 0.007 & 0.003 & 0.005 \\
\hline 5 & 1578 & Jl. Tukad Badung XX & 0.033 & 0.006 & 0.002 & 0.013 \\
\hline 6 & 893 & J1. Ciung Wanara VI & 0.029 & 0.028 & 0.003 & 0.013 \\
\hline 7 & 210 & Jl. Menuri & 0.029 & 0.023 & 0.001 & 0.005 \\
\hline 8 & 277 & J1. Gunung Batukaru & 0.031 & 0.031 & 0.007 & 0.013 \\
\hline & & Maximum Values $\left(\mathrm{A}^{*}\right.$ & 0.033 & 0.038 & 0.021 & 0.149 \\
\hline & & Minimum Values (A-) & 0.029 & 0.006 & 0.001 & 0.005 \\
\hline
\end{tabular}

Tujuan

Kriteria
danminimum(A-) dari nilaimasing masinguntuk setiap kriteria pada Tabel 4.

$$
\begin{aligned}
& A^{*}=(0.033,0.038,0.021,0.149) \\
& A^{-}=(0.029,0.006,0.001,0.005)
\end{aligned}
$$

d. Menentukan solusi idealpositif(PIS) dansolusi idealnegatif(NIS). Pengukuran Koefisien Kedekatan (CC) berdasarkan nilai $\mathrm{CC}$ tertinggih ke nilai $\mathrm{CC}$ terendah untuk menentukan urutan prioritas ruas jalan yang akan ditangani.

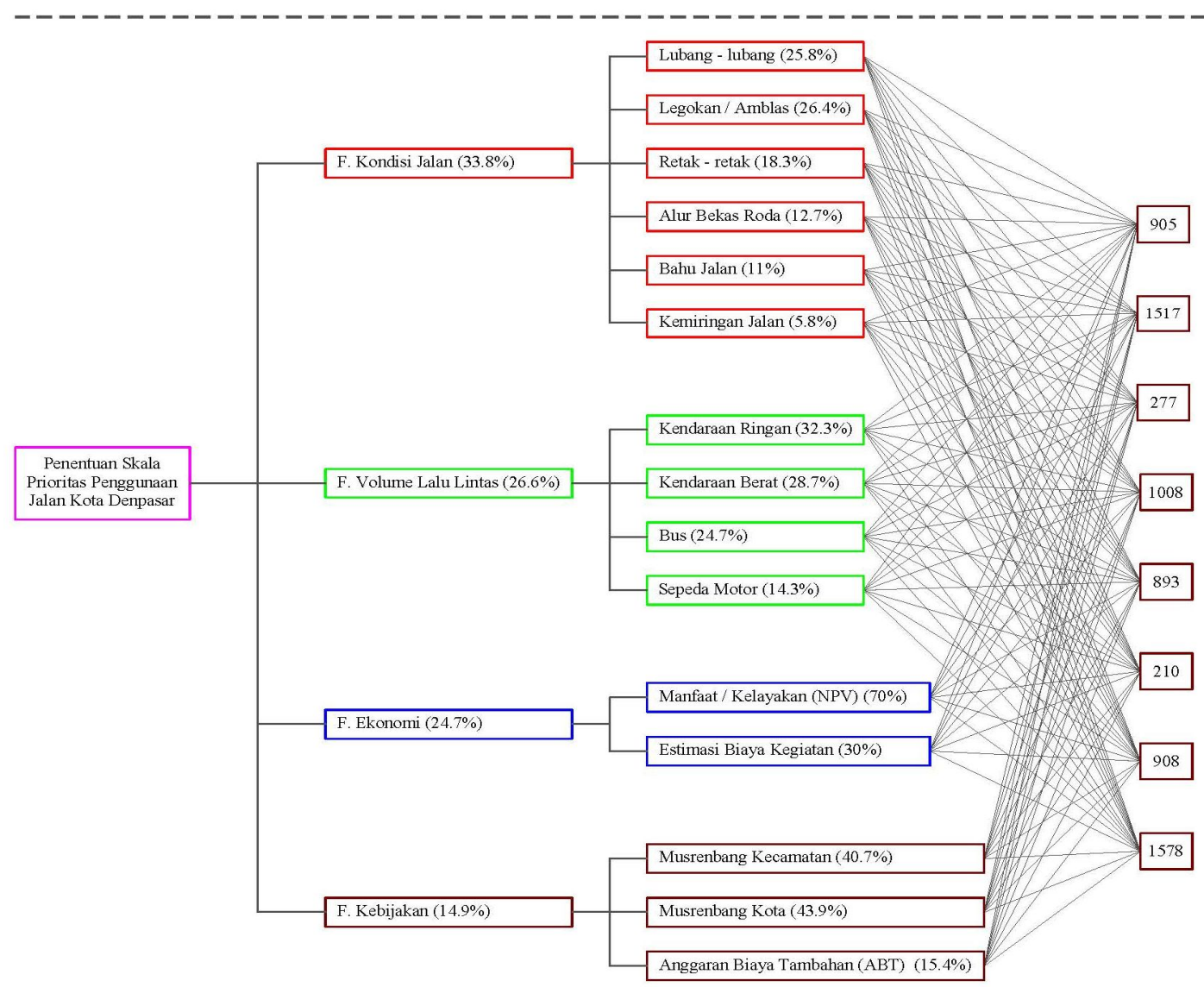

Gambar 4. Bobot Hirarki Penentuan Skala Prioritas Penanganan Jalan dengan Metode FAHP untuk Kelompok Jalan dengan Kondisi Rusak

c. Urutan prioritasdariruas jalanditentukan dengan menggunakanmetodeTOPSIS. Solusiidealpositif negatifditentukandengan mengambilmaksimum $(\mathrm{A}$
Perbandingan Skala Prioritas Penanganan Jalan Kota Denpasar dengan Metode SK. No. 77 Dirjen Bina Marga Tahun 1990, Metode AHPdan Kombinasi FAHP dan TOPSIS 
Perhitungan skala prioritas penanganan jalan berdasarkan metode SK. No. 77 Dirjen Bina Marga Tahun 1990, metode AHP, kombinasi metode FAHP dan TOPSIS dapat dilihat pada Tabel 4 berikut.

Tabel 4.Perbandingan Urutan Alternatif Prioritas Penanganan Jalan Kota Denpasar dengan Metode SK. No. 77, Metode AHP, Metode FAHP dan TOPSIS

\begin{tabular}{|c|c|l|c|c|c|}
\hline No & $\begin{array}{c}\text { No. } \\
\text { Ruas } \\
\text { Jalan }\end{array}$ & \multicolumn{1}{|c|}{ Nama Jalan } & $\begin{array}{c}\text { FAHP } \\
\text { dan } \\
\text { TOPSIS }\end{array}$ & $\begin{array}{c}\text { SK. } \\
\text { No. 77 }\end{array}$ & AHP \\
\hline \hline 1 & 905 & Jl. Waturenggong & 1 & 1 & 4 \\
2 & 1517 & Jl. Antasura & 2 & 2 & 1 \\
3 & 277 & Jl. Gunung Batukaru & 3 & 3 & 3 \\
4 & 1008 & Jl. Tukad Barito & 4 & 4 & 2 \\
5 & 893 & Jl. Ciung Wanara VI & 5 & 5 & 6 \\
6 & 210 & Jl. Menuri & 6 & 6 & 8 \\
7 & 908 & Jl. Tukad Banyupoh & 8 & 7 & 7 \\
8 & 1578 & Jl. Tukad Badung XX & 7 & 8 & 5 \\
\hline
\end{tabular}

Dari Tabel 4. di atas memperlihatkan metode AHP menghasilkan prioritas yang berbeda dengan metode SK. No. 77 Dirjen Bina Marga Tahun 1990 untuk ruas jalan nomor 905, 1517, 1008, 893, 210 dan 1578. Sedangkan untuk ruas jalan nomor 277 dan 908 menghasilkan urutan prioritas yang sama. Menariknya, metode FAHP dan TOPSIS memberikan hasil sama untuk keenam ruas jalan dari delapan ruas jalan yang ditinjau dengan metode SK. No. 77 Dirjen Bina Marga Tahun 1990

Metode FAHPdanTOPSIS yang menggunakan empatkriteria utama(kondisi jalan, volume lalu lintas, ekonomi dan kebijakan), sedangkanuntuk kasus di kota Denpasar, metode SK. No. 77 Dirjen Bina Marga Tahun 1990hanya mempertimbangkanLHR saja dalam menentukanurutan prioritaspenanganan jalan.Selain itu, kombinasi metode FAHPdanTOPSIStelah mempertimbangkanketidakjelasandankeragu raguandaripara pengambil keputusandibandingkan denganmenggunakan metode AHP.

\section{SIMPULAN DAN SARAN \\ Simpulan}

Dari hasil analisis yang telah dilakukan dapat diambil kesimpulan sebagai berikut :

1. Metode FAHPmenemukan bahwa kondisi jalan adalahfaktor yang paling pentinguntuk menentukanprioritaspenangananruas jalandi Kota Denpasar. Disisi lain, metode AHP juga menyarankankondisi jalansebagai faktor yang palingpenting dalam menentukanprioritaspenanganan jalan. Metode AHP dan metode FAHP memiliki kesamaan dalam urutan pembobotan kriteria, akan tetapi terdapat perubahan urutan pembobotan dalam sub kriteria untuk faktor kondisi jalan dan faktor kebijakan. Dalam metode AHP prioritas penanganan sub kriteria kondisi jalan dengan bobot tertinggi adalah lubang - lubang. Sedangkan dalam dengan metode FAHP prioritas penanganan pada sub kriteria kondisi jalan dengan bobot tertinggi adalah legokan/ amblas. Untuk faktor kebijakan terjadi perubahan urutan prioritas pembobotan pada Musrenbang Kecamatan dan Musrenbang Kota.

2. Metode AHP menghasilkan urutan prioritas yang berbeda dengan metode SK. No. 77 Dirjen Bina Marga Tahun 1990 untuk ruas jalan nomor 905, 1517, 1008, 893, 210 dan 1578. Sedangkan untuk ruas jalan nomor 277 dan 908 menghasilkan urutan prioritas yang sama. Menariknya, metode FAHP dan TOPSIS memberikan hasil sama untuk keenam ruas jalan dari delapan ruas jalan yang dianalisis dengan metode SK. No. 77 Dirjen Bina Marga Tahun 1990. Secara umum metodeAHPmemberikan hasil urutan prioritas penanganan jalan yang berbeda dengan metode SK. No. 77 Dirjen Bina Marga Tahun 1990. Di sisi lain, kombinasi metode FAHPdanTOPSISmemberikan hasil yang lebih mendekatimetodeSK. No. 77 Dirjen Bina Marga Tahun 1990.

\section{Saran}

Dari hasil simpulan penelitian ini adapun saran yang dapat diberikan adalah:

1. Pemerintah dalam hal ini Kementrian Pekerjaan Umum hendaknya menetapkan suatu metode/ SK. yang sesuai untuk 
menentukan prioritas penanganan jalan untuk jalan perkotaan.

2. Dalam menentukan skala prioritas penanganan jalan di Kota Denpasar, pemerintah kota sebaiknya mempertimbangkan penggunaan metode FAHP dan TOPSIS. Pertimbangan dari penggunaan metode FAHP dan TOPSIS dapat mengkombinasikan berbagai aspek dan kriteria yang dilakukan dengan pembobotan berdasarkan tingkat kepentingan, sehingga hasil urutan prioritas penanganan jalan yang dihasilkan lebih representatif. Selain itu masalah ketidaktepatan dan ketidakpastian seperti informasi yang tidak dapat dihitung, informasi yang tidak lengkap atau informasi yang diberikan baik oleh pengambil keputusan maupun data tentang atribut suatu alternatif tidak dapat disajikan atau tidak konsisten, maka metode ini dapat digunakan untuk menyelesaikan permasalahan.

\section{DAFTAR PUSTAKA}

Badan Pembangunan Daerah Kota Denpasar. 2010. Rencana Pembangunan Jangka Menengah (RPJM) Daerah Kota Denpasar 2010 - 2015, Denpasar

Brodjonegoro, P. S. 1991. Petunjuk Mengenai Teori dan Aplikasi dari Model The Analytic Hierarchy Process. Jakarta : Sapta Utama

Dinas Pekerjaan Umum. 2013. Daftar Ruas Jalan, Denpasar.

Direktorat Jenderal Bina Marga. 1990. Panduan Penentuan Klasifikasi Fungsi Jalan di Wilayah Perkotaan, Jakarta

Direktorat Jenderal Bina Marga. 1990. Petunjuk Teknis Perencanaan dan Penyusunan Program Jalan Kabupaten. Surat Keputusan No.77/KPTS/Db/1990. Jakarta: Dinas Pekerjaan Umum RI.

Karya, I W. 2004. "Skala Prioritas Penanganan Jaringan Jalan Pada Ruas-ruas Jalan Di Kabupaten Gianyar"(Tesis). Denpasar: Universitas Udayana

Prakash, T.N. 2003. "Land Suitability Analysis for Agricultural Crops: A Fuzzy Multicriteria Decision Making Approach" (MSc Thesis). The Netherlands : International Institute for Geo-Information Science and Earth Observation.
Putri, I D. A.N.A. 2011. "Penentuan Skala Prioritas Penanganan Jalan Kabupaten di Kabupaten Bangli” (Tesis). Denpasar : Universitas Udayana.

Saaty, T.L. 1986. Proses Hirarki Analitik untuk Pengambilan Keputusan Dalam Situasi yang Kompleks. Jakarta : PT Pustaka Binman Pressindo.

Suyasa, D.G. 2007, ’Penentuan Skala Prioritas Penanganan Jalan Kabupaten Badung dengan Metode AHP” (Tesis). Denpasar: Universitas Udayana.

Wedagama, D.M.P. 2010. 'Determining Regional Road Handling Priority Using Fuzzy Analytic Hierarchy Process (FAHP) and TOPSIS Method (Case Study : Badung Regency - Bali)". Jurnal Teknik Sipil ITB Vol. 17 No.2 Agustus 2010.

Wedagama, D.M. P and Frederika, A. 2011. "Applying Fuzzy Analytic Hierarchy Process (FAHP) $\alpha$ - Cut Based and TOPSIS Methods to Determine Bali Provincial Road Handling Priority". Civil Engineering Dimension. Vol.13, No.2 September 2011.96-106 